\title{
Transmissible Venereal Tumor Associated with Cutaneous Metastasis and Leishmaniasis in a Bitch
}

\author{
Leidiane Uchôa Soares Diamantino', Angélica Prado de Oliveira', \\ Kaenna dos Santos Andrade', Marcos Wilker da Conceição Santos' , Zayan Silva Pereira', \\ Filipe Lucas de Melo Mendonça² \& Layze Cilmara Alves da Silva Vieira'
}

\begin{abstract}
Background: The Transmissible Venereal Tumor (TVT) is a round cell neoplasia, of contagious nature, common in the canine species, which mainly affects external genitalia. Despite metastasis being uncommon, the extragenital involvement can occur via the lymphatic or hematogenous route to regional lymph nodes, skin, subcutaneous tissue, nasal and oral mucosa, as well as the central nervous system. When the location of the tumor is genital the clinical diagnosis can be conclusive, however if it presents extragenital forms, cytological or histopathological studies are necessary for the confirmation. This work describes a case of TVT with cutaneous metastasis in a female dog with leishmaniasis.

Case: A 3-year-old crossbred female dog was attended at the Small Animal Medical Clinic (CMPA) of the University Veterinary Hospital (HVU) of the Federal University of West Bahia (UFOB), Barra Multidisciplinary Center. This neutered bitch dewormed, never vaccinated, rescued from the streets at the age of two and a half, had a prior history of ehrlichiosis and pyometra. The owner reported apathy, anorexia, cachexia, depression and sternal decubitus of the animal, as well as episodes of vomiting and recurrent fever. During the physical examination were observed respiratory and heart rates within normality ranges, with predominance of slightly pale mucous membranes, reactive left prescapular lymph node and subcutaneous nodular mass, not adhered to the musculature, located in the medial portion of the thirteenth left rib. Were also evidenced onychogryphosis, opaque, shineless and brittle fur, with pruritic and lichenified exfoliative dermatitis in the left scapular region, ear tips and snout, presence of a discreet quantity of brownish-colored vulvar discharge with a putrid odor. In the cytological examination, was verified the presence of cells with characteristics of TVT located in the genital mucosa, developing atypical metastasis in the cutaneous tissue in the region of the thirteenth rib, and by means of the cytomorphometric analysis of the extracellular matrix of the left popliteal lymph node, confirmed positivity for leishmaniasis. The symptomatic treatment was started aiming to restore the patient for subsequent treatment of the TVT and leishmaniasis, however, due to the non-responsiveness and worsening of the clinical picture, the owner opted for the euthanasia of the animal.

Discussion: It is possible to conclude that the TVT can affect extragenital locations, although it is considered to be rare. Emphasizing that the canine species is regarded as an important reservoir of Leishmania sp., with a prominent role in the maintenance and interaction between the cycle of the disease, attention is drawn in this case for the risk to One Health, as the contact of this dog with phlebotomines, may have enabled, whilst alive, the perpetuation and transmission of the disease to other susceptible animals and human beings. As they are distinct diseases, but with pronounced rates of immunosuppression, when TVT and leishmaniasis occur in association, they generate a concerning state of debility which hinders the adoption of efficient therapeutic measures for both illnesses. Cytology is a diagnostic technique, which should whenever possible be routinely associated to the clinical examination in the veterinary practice, as it is of easy performance, low cost and great value in the determination of the diagnosis of neoplasia, identification of parasites and several other affections.
\end{abstract}

Keywords: canine, cytology, neoplasia, genital mucosa, Leishmania sp.

DOI: $10.22456 / 1679-9216.108475$ 


\section{INTRODUCTION}

The Transmissible Venereal Tumor (TVT) is a neoplasia included in the group of round cells, common in the canine species mainly affecting the external genitalia.

Despite metastasis in cases of TVT being uncommon, with incidences varying from 0 to $17 \%$ [20], the extragenital involvement can occur via the lymphatic or hematogenous $[9,19,21]$.

The factors that cause the dissemination of the tumor are related to malnutrition and/or immunosuppression [10]. Among these are quotes, some infectious or parasitic diseases, as for example leishmaniasis, a tropical disease caused by protozoans of the genus Leishmania, transmitted by phlebotomines, especially those of the species Lutzomyia longipalpis.

Macroscopically the TVT exhibits a cauliflower-like appearance, pedunculated, in the form of an ulcerated mass, friable with hemorrhagic diatheses, whilst in the cutaneous tissue presents firm nodules, with papillary or multilobated characteristics, there may also be some associated inflammatory process $[5,19]$. When the location of the tumor is genital the clinical diagnosis can be conclusive, however if it presents extragenital forms it is necessary to conduct cytological or histopathological studies for the confirmation.

Chemotherapy has been the most recommended treatment, due to the good pharmacological response and the possibility of recurrence with the surgery $[17,20]$. The prognosis is favorable, except for the cases that present metastasis or resistance to chemotherapy [23]. This work describes a case of TVT with cutaneous metastasis in a female dog with leishmaniasis.

\section{CASE}

A 3-year-old crossbred female dog was attended at the Small Animal Medical Clinic (CMPA) of the University Veterinary Hospital (HVU) of the Federal University of West Bahia (UFOB), Barra Multidisciplinary Center. This neutered bitch dewormed, never vaccinated, rescued from the streets at the age of two and a half, had a prior history of ehrlichiosis and pyometra (treated with antibiotics and elective ovariohysterectomy surgery). The owner reported apathy, anorexia, cachexia, prostration and prolonged sternal decubitus for eight days, as well as recurrent vomiting and fevers. During the physical examination were observed respiratory and heart rates within the normality rate, with predominance of slightly pale mucous membranes, reactive left prescapular lymph node and a nodular mass non-adhered to the musculature, located in the medial portion of the thirteenth left rib. It were also evidenced $7 \%$ dehydration, onychogryphosis, opaque, shineless and brittle fur (Figure 1A), with pruritic and lichenified exfoliative dermatitis observed in the left scapular region (Figure 1B), on the ear tips and snout, and was verified the presence of a brownish-colored vulvar discharge, in a discreet quantity and with a putrid odor (Figure 1C).

Blood samples were collected, and by means of fine needle aspiration puncture (FNAP), aspirated from the nodule and popliteal lymph node, as well as slide imprints of the vaginal region, these were sent to the Veterinary Clinical Pathology Laboratory of the same institution.

The hematological examination revealed: normocytic hypochromic anemia, associated to moderate anisocytosis, thrombocytopenia and leukocytosis by neutrophilia.

The vaginal cytological examination, revealed a monomorphic populations of large cells with round nucleus, condensed chromatin and one to two prominent nucleoli, abundant and slightly basophilic cytoplasm, with multiple dotted vacuoles, confirming a case of TVT, additionally, was evidenced the presence of cocci, rods, and intense neutrophilia, indicating an inflammatory process associated to the bacterial infection. A similar cellular finding was verified in the nodular mass, confirming the occurrence of cutaneous metastasis of the TVT (Figure 2A).

The cytomorphometric analysis of extracellular matrix of the left popliteal lymph node, demonstrated the presence of amastigote forms of the protozoan Leishmania sp., with basophilic coloring, comma-shaped and in the interior of the macrophages, conforming a case of leishmaniasis (Figure 2B).

The symptomatic treatment was initiated in the clinic with the administration of ringer's solution without lactate, $0.52 \mathrm{~mL} / \mathrm{kg}$ of amoxicillin trihydrate $\left(\text { Agemoxi }^{\circledR} 100 \mathrm{~mL}\right)^{1}$ via intramuscular route, $0.26 \mathrm{mg} / \mathrm{kg}$ of Ranitidine (Hipolabor $\left.{ }^{\circledR}\right)^{2}$ via intravenous route and $1 \mathrm{~mL} \mathrm{mg} / \mathrm{kg}$ of Mercepton antitoxic $\left(\text { Bravet }^{\circledR}\right)^{3}$ intramuscularly. The hospitalization of the animal was recommended, as well as to await for the recovery of the general symptomatology, in order to initiate the specific therapeutics for TVT and leishmaniasis. The owner opted not to carry out in a continuous 
L.U.S. Diamantino, A.P. Oliveira, K.S. Andrade, et al. 2021. Transmissible Venereal Tumor Associated with Cutaneous

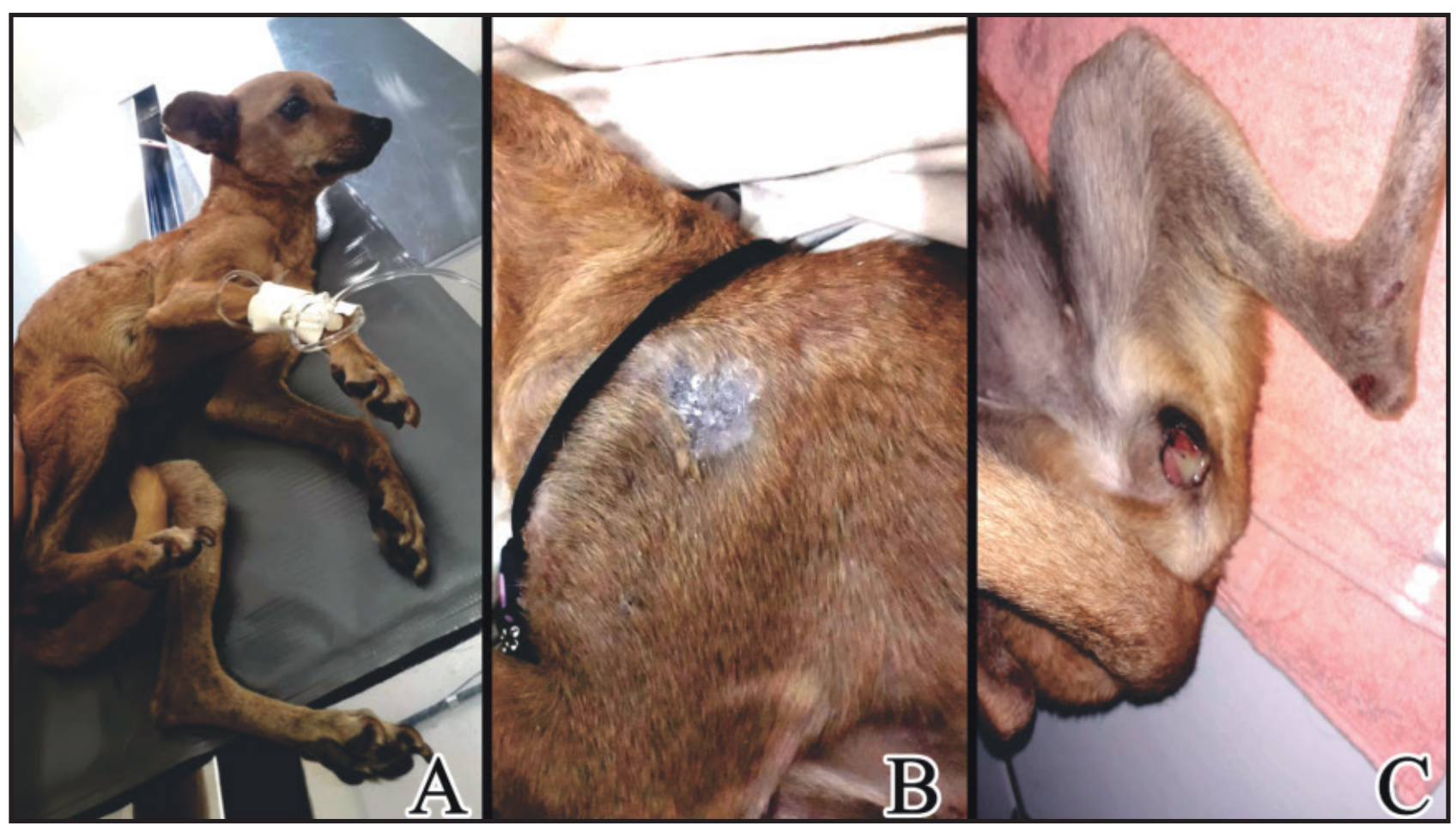

Figure 1. Clinical Picture. A- Cachexia, apathy and onychogryphosis, opaque, shineless and brittle fur. B- Presence of pruritic and lichenified exfoliative dermatitis in the left prescapular region. C- Serosanguinolent secretion in the vulvar mucosa.

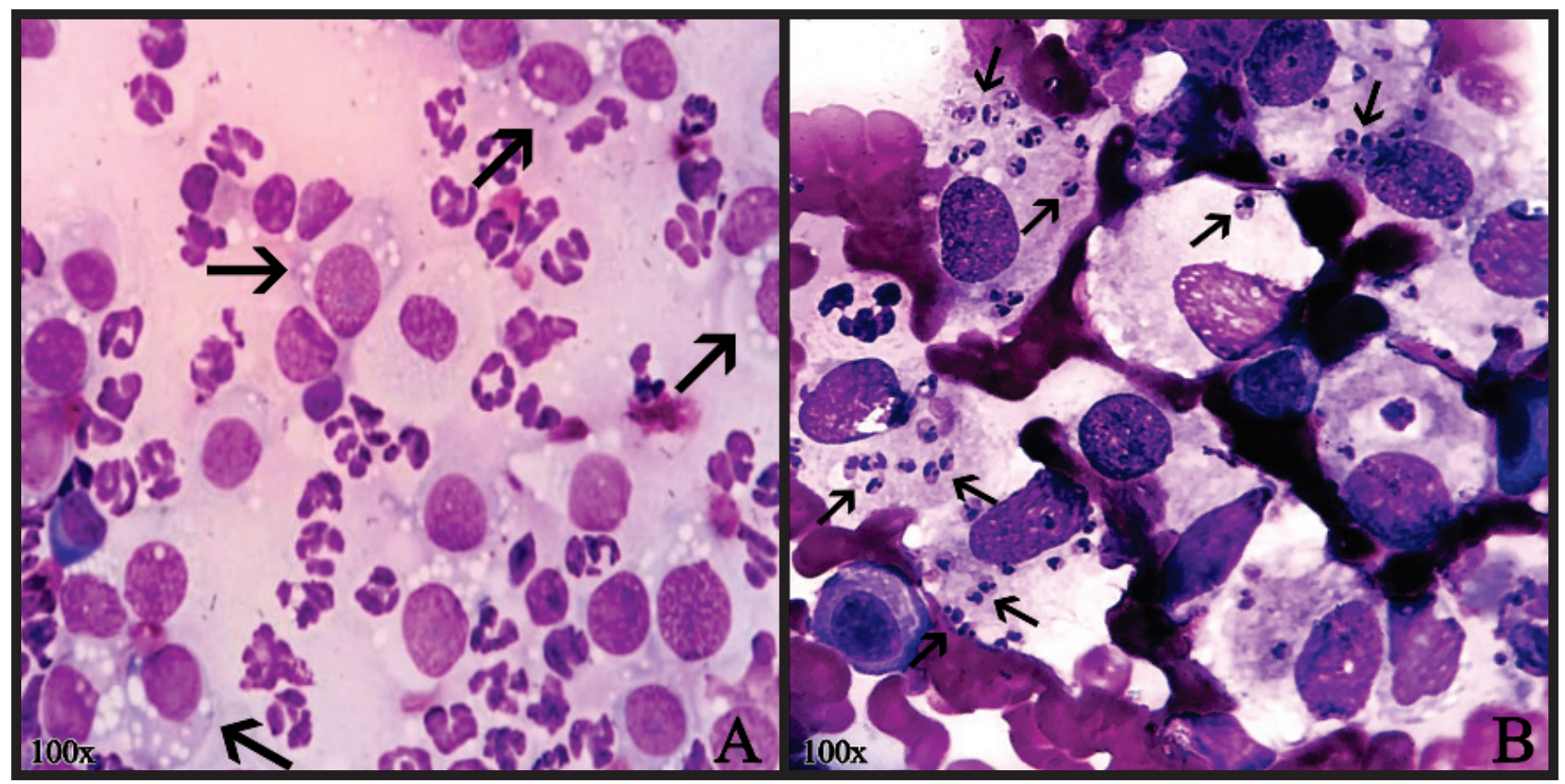

Figure 2. Cytological Diagnosis. Transmissible Venereal Tumor. A- The presence of round cells with circular nucleus, abundant and lightly basophilic cytoplasm with multiple dotted vacuoles was observed [Fast Panoptic; 100x]. Cells harvested from the left popliteal lymph node. The presence of the amastigote form of Leishmania sp. is observed in the cytoplasm [Fast Panoptic; 100x].

form the drug therapy, reporting adverse effects and worsening of the dog's clinical condition (prostration, inappetence and non-responsive animal). With the owner's authorization, the animal was euthanized and sent to anatomopathological examination.
During the necropsy, was noticed intense cachexia (Figure 3A). Splenomegaly was identified in the spleen, with the visualization of rounded borders, natural surface with whitish multifocal and rigid areas, presenting fibrosis and healed rupture in the dorsal pole 
L.U.S. Diamantino, A.P. Oliveira, K.S. Andrade, et al. 2021. Transmissible Venereal Tumor Associated with Cutaneous

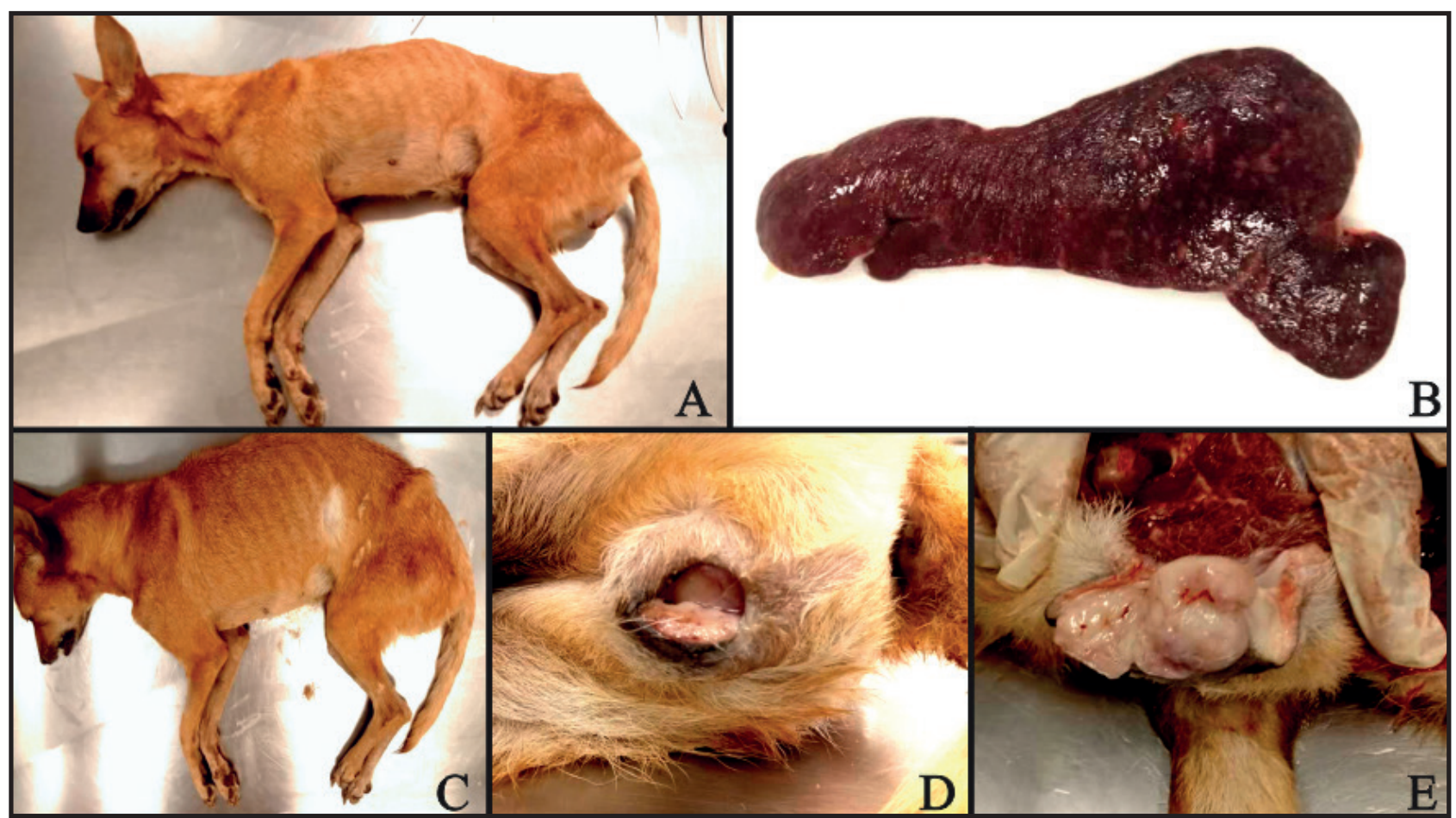

Figure 3. Necropsy. A- Intense cachexia. B- Spleen, splenomegaly is observed, rounded borders, natural surface with whitish and rigid multifocal areas, presenting fibrosis and healed rupture in the dorsal pole. C- Trichotomized nodule presenting $1.5 \mathrm{~cm}$, rigid, non-adhered and located in the subcutaneous tissue on the medial portion of the thirteenth left rib. D- Longitudinal opening of the vagina, evidence of a multinodular, irregular and whitish mass. E- Whitish multinodular mass, occupying both sides of the vulva.

(Figure 3B). A non-ulcerated nodule was observed in the subcutaneous, in the left lateral region on the $13^{\text {th }}$ rib, measuring $1.5 \mathrm{~cm}$ of length and $0.5 \mathrm{~cm}$ of width, rigid, whitish and non-adhered to the musculature (Figure 3C), at cut, presented the same aspects as the fragment collected from the mass located in the vulvar region, with multinodular characteristic, whitish coloring, rigid, easy bleeding at manipulation and intense odor (Figure 3D \& 3E).

\section{DISCUSSION}

Through the presented report it is noticeable the importance of complementary diagnostic tests in the routine of veterinary clinics and hospitals. It was evidenced that the anamnesis and physical state of the evaluated animal, indicated a condition of genital affection, associated to skin problems and apathy, which by means of cytological examinations, confirmed TVT with cutaneous metastasis associated with leishmaniasis.

As it is an oncological pathology which has the characteristic of cell implantation with tissue proliferation in genital regions of dogs, social factors predispose the dogs to acquire this affection, as for example, free access to the street without the presence of the owner, agglomerations, uncontrolled population of stray dogs and contact with sick animals $[1,11,12]$, factors which were present in the routine of the animal of this study.

Possibly the canine reported in this work, already had TVT when adopted, taking into consideration the extension size of the genital mass and the chronological evolution mentioned by the owner (six months) until the presentation of the first signs (bleeding initially of a bright red coloring and subsequently brownish-colored with a putrid odor), as well as the absence of contact with other dogs throughout that period. The decrease of the animal's immunity, associated to the inability of coping with the therapeutics suggested for the remission of the disease, may have implied in the cutaneous metastasis of the TVT, which increased the severity of the case [10]. The occurrence of metastasis of the TVT to the subcutaneous tissue can be considered to be secondary to a primary genital focal point, while in cases of oral, nasal and ocular mucous membranes are reported as being of primary occurrence, due to olfaction being a social factor of the dogs, it enables contact of the mucous membranes with the genital mucosa and/or secretions of other animals which are carriers of the affection [10].

The apathy and prostration described in the animal are possibly a result of the state of cachexia 
and normocytic hypochromic anemia it presented, this, generally occurs when the number of macrocytes and microcytes is insufficient to cause an alteration in the Mean Corpuscular Volume (MCV), the hypochromia can be a result of the occurrence of immature cells in the bloodstream, created due to a hemoglobin concentration which is insufficient to inhibit another mitosis [22]. With the limited capacity of the blood to carry oxygen to the tissues, the cells do not perform their normal function and the animal becomes debilitated, intolerant to exercise and prostrated [14].

The bacterial infection evidenced in the vaginal cytological diagnosis is probably secondary to the neoplasia and the state of immunosuppression. Possibly caused by the sensitivity and proximity of the affected area with the external environment, as well as the animal's habits of licking, which according to Silva et al. [20], are risk factors that propitiate the carrying of microorganisms to various corporal regions.

The cytology of the left popliteal lymph node, provided the observation of amastigote forms of the protozoan Leishmania sp., a comma-shaped hemoparasite of basophilic coloring, and in the interior of the macrophages, confirming a case of leishmaniasis [21]. Studies have proved the presence of phlebotomines of the species Lutzomyia longipalpis in the Barra region, West of Bahia, highlighting the canine population as one of the main ones involved in its blood repast [8]. The presence of ulcerative lesions and secretions, characteristic of neoplasia, may have propitiated the attraction of the L. longipalpis females, vectors of the protozoans of the genus Leishmania, entailing higher possibilities of infection $[10,16]$. High parasitemia levels can be correlated in this animal due to the intense infection by the protozoans observed in the cytology, which probably indicates the acute phase of the infection, period in which the multiplication and development of the agent is greater [6], consequently, enabling the visualization of the protozoan with greater ease. It is hypothesized that due to the genital affection and the stress levels caused by it, a high liberation of cortisol occurred, inducing immunosuppression of the defense cells of the organism [14]. Resulting in small and constant failures in combating the parasitosis.

The clinical manifestations of leishmaniasis depend on the type of immunological response (T helper 1 (Th1) and T helper 2 (Th2)) expressed by the infected animal, and can be classified in asymptomatic, oligosymptomatic and symptomatic dogs. The Th2 response generates more severe and chronic clinical signs $[3,15]$, what may have occurred with the animal of this study, influencing its immunosuppression and debility, implying a more severe condition of TVT with metastasis, demonstrated in the complication generated by the association of the two diseases, as previously described [7] for other debilitating parasitic infections, Dirofilaria immitis and/or Spirocerca lupi, which occurred simultaneously to the metastasis of the TVT. The clinical signs evidenced, such as onychogryphosis and cutaneous alterations, especially on the ear tips and snout, are in accordance with literature, referred to the classification of symptomatic dogs infected with leishmaniasis [15].

During the necropsy was evidenced genital TVT, confirmed by the visualization of a whitish-colored multinodular mass, occupying both sides of the vulva with a cauliflower-shaped surface, varying from friable to firm, hemorrhagic, in conformity to the literature [4]. It aas highlighted a nodule located in the subcutaneous region (suggesting metastasis of the neoplasia), this nodule presented a non-ulcerated characteristic, corroborating with prior study [2] that described the presence of a genital TVT for a long period of time associated to immunosuppression, propitiates the occurrence of extragenital metastasis. Literature also reports that, extragenital nodules located in the skin have an ulcerative characteristic as a result of the implantation of cells of the oral or nasal mucosa of dogs with TVT by means of the mechanical transplant after traumatisms (bites) [18], characterizing these nodules as a primary neoplasia. The nodule reported did not have ulcerative characteristics, suggesting that it is a metastasis originating from the mass present in the external genitalia.

Diffuse splenomegaly (meaty spleen) was evidenced, with observation of hyperplasia white pulp. Such alterations can be explained as a result of the infection by protozoans of the genus Leishmania [13]. In its physiology the spleen has functions of filtration, and immunological, storing and hematopoiesis functions. During an infection by Leishmania sp. the immunological functions of the spleen are activated for the depletion of this pathogenic agent. Within the life-cycle of the Leishmania the macrophages, belonging to the monocytic-macrophagic system are recruited to compose the red pulp of the organ, are infected for 
the transformation and multiplication of the parasite, terminating with the death of the macrophage and new infection [13]. Due to this immune response, the vascular spaces respond with the increase of the volume of the red pulp with macrophage aggregates and congestion to aggressions. The characteristic of firm consistency (meaty spleen) may result from mechanisms such as phagocytosis and proliferation of cells [13], which promoted a hyperplasia of the cells of structure of the splenic white pulp.

Emphasizing that the canine species is seen as na important reservoir of Leishmania sp., with a with a prominent role in the maintenance and interaction between the cycle of the disease, attention is drawn in this case to the risk to One Health, as the contact of this dog with phlebotomines, may have enabled, whilst alive, the perpetuation and transmission of the disease to other susceptible animals and human beings.

As they are distinct diseases, but with pronounced immunosuppression rates, when TVT and leishmaniasis occur in association, generate a concerning state of debility, hindering the adoption of efficient therapeutic measures for both illnesses.

The understanding of the behavior of the extragenital TVT, can clarify important points about the populations, which are susceptible to this disease, as well as to provide significant data on its prevalence, diagnosis and treatment. Furthermore, to understand the details of the transmission of the tumor is necessary in order to comprehend its most aggressive forms, seen as the TVT presents a high incidence and clinical importance mainly, due to the great quantity of stray animals, often immunosuppressed by malnutrition and other diseases which may favor the metastasis process, as presented in the present report. Thus, it is important to think of the TVT as differential diagnosis when observing nodules in extragenital tissues, especially in regions endemic to the disease.

Cytology is a diagnostic technique, which should be, whenever possible, associated with clinical examination routinely in veterinary practice, as is it easy to perform, because of its low cost and great value in the determination of the diagnosis of neoplasias, identification of parasites and other affections.

\section{MANUFACTURERS}

${ }^{1}$ União Química Farmacêutica Nacional S.A. Embu-Guaçu, SP, Brazil.

${ }^{2}$ Hipolabor Farmacêutica Ltda. Sabará, MG, Brazil.

${ }^{3}$ Laboratório Bravet Ltda. Santa Cruz, RJ, Brazil.

Declaration of interest. The authors report no conflicts of interest. The authors alone are responsible for the content and writing of the paper.

\section{REFERENCES}

1 Amaral A.S., Gaspar L.F.J., Silva S.B. \& Rocha N.S. 2004. Diagnóstico citológico do Tumor Venéreo Transmissível na região de Botucatu, Brasil (estudo descritivo: 1994-2003). Revista Portuguesa de Ciências Veterinárias. 99(551): 167-171.

2 Batista J.S., Soares H.S., Pereira R.H.M.A., Petri A.A., Sousa F.D.N. \& Nunes F.C.R. 2007. Tumor Venéreo Transmissível canino com localização intra-ocular e metástase no baço. Acta Veterinária Brasílica. 1(1): 45-48.

3 Brasil. 2006. Ministério da Saúde. Manual de vigilância e controle da Leishmaniose Visceral. Brasília, DF: Editora do Ministério da Saúde. Disponível em: <http://bvsms.saude.gov.br/bvs/publicacoes/manual_vigilancia_controle_leishmaniose_visceral.pdf>.

4 Calderon C., Oliveira R.R., Marquez E.S. \& Cruz M.F.R. 2016. Aspectos anatomopatológicos do Tumor Venéreo Transmissível canino. Scientific Electronic Archives. 9(4): 101-113.

5 Camolese L.C., Bergano T.M., Barros V.T.M., Voorwald F.A., Toniollo G.H. \& Friolani M. 2016. Tumor Venéreo Transmissível com metástase cutânea e ocular em cão: relato de caso. Unimar Ciências. 25(1-2): 28-31.

6 Carneiro M.E. 2017. Protozoários flagelados. In: Monteiro S.G. (Ed). Parasitologia na Medicina Veterinária. 2.ed. Rio de Janeiro: Roca, pp.139-141.

7 Chikweto A., Kumthekar S., Larkin H., Deallie C., Tiwari K.P., Sharma R.N. \& Bhaiyat M.I. 2013. Genital and extragenital canine Transmissible Venereal Tumor in dogs in Grenada, West Indies. Open Journal of Veterinary Medicine. 3(2): 111-114.

8 Cordeiro A.K.P., Fagundes A.I.S., Silva C.M.A., Silva M.B., Conceição M.S. \& Magalhães Junior J.T. 2018. Ocorrência de flebotomíneos na zona urbana do município de Barra, Bahia. In: $54^{\circ}$ Congresso da Sociedade Brasileira de Medicina Tropical (Olinda, Brazil). R0455. 
9 Fabiano C., Frangueli J.S., Marques V. \& Torres A.P.C. 2017. Tumor Venéreo Transmissível. Revista Conexão Eletrônica. 14(1): 1904-1911.

10 Fernandes C.P.M., Gaspar L.F.J., Meinerz, A.R.M., Grecco F.B., Nobre M.O. \& Cleff M.B. 2013. Tumor Venéreo Transmissível canino com metástase encefálica. Semina: Ciências Agrárias. 34(6 Suppl 2): 3929-3934.

11 Ferreira M.A.Q.B., Teixeira M.N., Carvalho C.C.D., Paiva B.H.A., Silva V.C.L., Fukahori, F.L.P., Rêgo M.S.A., Dias M.B.M.C. \& Lima E.R. 2017. Aspectos clínicos, hematológicos, bioquímicos e citopatológicos do Tumor Venéreo Transmissível em cães tratados com sulfato de vincristina. Medicina Veterinária (UFRPE). 11(1): 8-17.

12 Filgueira K.D. 2010. Tumor Venéreo Transmissível canino com localização primária e única em cavidade oral. Acta Scientiae Veterinariae. 38(1): 91-94.

13 Fry M.M. \& McGavin M.D. 2013. Medula óssea, células sanguíneas e sistema linfático. In: Zachary J.F. \& Mc Gavin M.D. (Eds). Bases da Patologia em Veterinária. 5.ed. Rio de Janeiro: Elsevier, pp.740-764.

14 Lopes S.T.A., Biondo A.W. \& Santos A.P. 2007. Manual de Patologia Clínica Veterinária. 3.ed. Universidade Federal de Santa Maria / Departamento de Clínica de Pequenos Animais. Santa Maria: UFSM-CCR, 107p.

15 Moreira M.L. 2013. Duração da imunidade vacinal na Leishmaniose visceral canina: Perfil fenotípico e funcional da atividade fagocítica anti-Leishmania chagasi. 131f. Belo Horizonte, MG. Dissertação (Mestrado em Ciências) - Programa de Pós-Graduação em Ciências da Saúde do Centro de Pesquisas René Rachou, Fundação Oswaldo Cruz.

16 Mota L.A.A \& Miranda R.R. 2011. Manifestações dermatológicas e otorrinolaringológicas na Leishmaniose. Arquivos Internacionais Otorrinolaringologia. 15(3): 376-381.

17 Moura A.L., Jorge S.M., Alencar E.C., Silva Júnior J.A. \& Silva I.N.G. 2018. Abordagem clínica e laboratorial de Tumor Venéreo Transmissível (TVT) em uma cadela prenhe. Ciência Animal. 28(2): 104-112.

18 Moutinho F.Q., Sampaio G.R., Teixeira C.R, Sequeira J.L. \& Laufer R. 1995. Tumor Venéreo Transmissível com metástases em um cão. Ciência Rural. 25(3): 469-471.

19 Rogers K.S., Walker M.A. \& Dillon H.B. 1998. Transmissible Venereal Tumor: a retrospective study of 29 cases. Journal of the American Animal Hospital Association. 34(6): 463-470.

20 Silva M.C.V., Barbosa R.R., Santos R.C., Chagas R.S.N. \& Costa W.P. 2007. Avaliação epidemiológica, diagnóstica e terapêutica do Tumor Venéreo Transmissível (TVT) na população canina atendida no Hospital Veterinário da UFERSA. Acta Veterinária Brasílica. 1(1): 28-32.

21 Solano-Gallego L. 2012. Sistema reprodutivo. In: Raskin R.E. \& Meyer D.J. (Eds). Citologia Clínica de Cães e Gatos: Atlas Colorido e Guia de Interpretação. 2.ed. Rio de Janeiro: Elsevier, pp. 547-622.

22 Thrall M.A. 2015. Classificação e abordagem diagnóstica da anemia. In: Thrall M.A., Weiser G., Allison R.W. \& Campbell T.W. (Eds). Hematologia e Bioquímica Clínica Veterinária. 2.ed. Rio de Janeiro: Editora Roca, pp.171-179.

23 Woods J.P. 2013. Miscellaneous Tumors. In: Withrow S.J., Vail D.M. \& Page R.L. (Eds). Small Animal Clinical Oncology. 5th edn. St. Louis: Elsevier, pp.692-696. 